\title{
AQUISIÇÃO DE DIREITOS REAIS POR COMPRADOR DE LOTEAMENTO REGULAR.
}

\section{Francisco Bertino Bezerra de Carvalho*}

\section{RESUMO}

A partir do sistema de controle da propriedade imobiliária no Brasil, do regramento relacionado ao fracionamento de propriedades para loteamento e da aquisição de direitos reais pelo Poder Público a partir da aprovação administrativa de loteamento urbano, o trabalho aborda a possibilidade de aquisição de direitos reais também pelos compradores de lotes em virtude das regras expressas da lei e do próprio sistema jurídico.

PALAVRAS CHAVE: Loteamento Regular. Direito Adquirido. Adquirente. Direitos reais.

\section{ACQUISITION OF REAL RIGHTS BY URBAN ALLOTMENT BUYER}

\begin{abstract}
From the real estate property control system in Brazil, the rule related to fractionation of properties for allotment and the acquisition of real rights by the Public Power from the administrative approval of urban subdivision, this papper deals with the possibility of acquiring real rights also by the purchasers of lots by virtue of the express rules of the law and of the legal system itself
\end{abstract}

KEY WORDS. Regular urban allotment. Acquired right. Buyer. Rights in rem.

\section{1) INTRODUÇÃ̃O.}

O direito de propriedade imobiliária no Brasil vinculou-se ao sistema registral, feita a opção por importar o modelo alemão. A legislação brasileira estruturou o modo de controle da transferência e formação da cadeia sucessória no registro público no cartório de imóveis com competência territorial sobre a localização do bem, como se vê no tópico dois.

O loteamento urbano no país segue regramentos próprios, segundo os quais o registro do projeto aprovado pela Prefeitura (ou Estado) no Cartório de Imóveis é o marco temporal da aquisição da propriedade dos bens públicos. Para os particulares, o contrato de aquisição de lote, desde que devidamente pago, confere-lhes direito real, como ratifica o Código Civil e interpretação doutrinária e jurisprudencial do tema, como registra o tópico três.

\footnotetext{
* Advogado, Procurador do Município do Salvador, Professor Adjunto de Direito Processual Civil da UFBA, Mestre em Direito Econômico pela UFBA, Doutor em Direito Público pela UFBA. Vice-Diretor da Faculdade de Direito da UFBA. Coordenador do Curso de Graduação da UFBA. Al. das Samambaias, 375, Horto Ville Piatã, Villa dos Ipês, nº 24, Piatã, Salvador, Bahia, Brasil, CEP 41.650-230. fbc@eabl.com.br
} 
Doutrina e jurisprudência já convergem para a aquisição da propriedade pelo Poder Público dispensar o registro, dependendo apenas da aprovação do projeto pela própria Prefeitura, inclusive sem a implantação física do loteamento, como visto no tópico 3.1.

A aquisição da propriedade pelo particular, todavia, continua sendo associada à quitação integral do preço, criando uma assimetria com o Poder Público, dono de suas áreas deste a aprovação do loteamento, situação que se torna gravosa quando (o que ocorre com infeliz frequência) os loteadores abandonam as obras inacabadas e os adquirentes, em muitas ocasiões, terminam sem o imóvel e sem o numerário correspondente ao pagamento feito. O prejuízo nestes casos não se resume aos compradores, mas à sociedade (sem o empreendimento) e ao próprio Município, sem a ocupação ordenada do solo previamente projetada.

A questão a posta à exame no tópico 3.2 é, a partir de particularidades do regime jurídico do loteamento com relação à transferência de direitos reais para o Poder Público e para particulares, analisar quais direitos os compradores de lotes incorporam ao seu patrimônio com a celebração do negócio jurídico e até que ponto estes direitos tem natureza real e são oponíveis contra terceiros e contra a Administração Pública, até para exigir-lhe a conclusão da obra.

\section{2) O DIREITO DE PROPRIEDADE NO BRASIL - PROPRIEDADE IMÓVEL.}

O direito de propriedade é uma garantia constitucional prevista no caput do art. $5^{\circ}$ da Carta Magna também elencado pela Constituição Federal dentre os princípios gerais da atividade econômica no título que trata da ordem econômica e financeira:

Art. 170. A ordem econômica, fundada na valorização do trabalho humano e na livre iniciativa, tem por fim assegurar a todos existência digna, conforme os ditames da justiça social, observados os seguintes princípios: [...]

II - propriedade privada;

O rol de princípios gerais da atividade econômica também inclui no mesmo art. 170 a função social da propriedade (inciso III), assim como, segundo seu parágrafo único é: "assegurado a todos o livre exercício de qualquer atividade econômica, independentemente de autorização de órgãos públicos, salvo nos casos previstos em lei”.

A propriedade imobiliária no Brasil resulta de inscrição e registro no Cartório de Imóveis com jurisdição territorial. Para compreender o sistema registral pátrio é necessário conhecer suas origens. Entre os países ibéricos, com forte influência no Brasil Colônia, na Espanha, o Direito registral é semelhante ao sistema registral germânico. Em Portugal, os diplomas encontrados nas ordenações Afonsinas, Manuelinas e Filipinas persistiram no 
princípio romano da tradição, como modo de aquisição e perda da propriedade, mantendo toda estrutura romana de regulação.

A monarquia brasileira recepcionou o direito português, mas começou a desenvolver o direito nacional. Na época, tanto na Alemanha quanto na França, a busca de um mecanismo que desse segurança ao crédito fomentou a criação de um registro de hipotecas que, ao evoluir, originou todos os outros direitos reais sobre imóveis. No Brasil não foi diferente, sua economia essencialmente agrícola, a necessidade do crédito tornou realidade o primeiro regulamento hipotecário de 1846, dando origem ao Registro Geral de Hipotecas.

Já o sistema francês fundou-se na vontade (consentimento), como suficiente para gerar ou extinguir o direito real. O Código Civil Napoleônico aboliu a legislação que criara a necessidade de transcrição do contrato, seja como modo de aquisição ou perda da propriedade sobre bem imóvel, seja como forma de publicidade perante terceiros. Desta forma, na França, a transmissão do domínio resulta da vontade contratual entre alienante e adquirente. Apesar disso, após a regulamentação do sistema hipotecário francês, em 23/3/1855, surgiu a necessidade de transcrição do contrato e tradição, visando dar publicidade a terceiros. $\mathrm{O}$ contrato (acordo de vontades) continua a ser o elemento que origina o direito real, no Direito francês.

No sistema germânico, a partir de 1794, com a concepção do Hauptbuch, vincula cada imóvel a uma folha (fólio real) na qual deveriam ser feitas todas as anotações de propriedade e de seus ônus, mesmo sistema do Código Civil Austríaco. Nestes países, o registro feito no distrito da situação do imóvel tornou-se obrigatório. Fora dos livros respectivos não era possível constituir, transferir ou extinguir direitos reais. Na Alemanha, somente a transcrição é modo de perda ou aquisição dos direitos reais, do que se extrai presunção absoluta de propriedade em favor do titular. Perda ou aquisição condicionam-se ao registro do título imobiliário. Em suma, titular é aquele que consta do registro, ou, como alardeiam os cartórios de registro de imóveis nem suas campanhas de publicidade: só é dono quem registra. Esta presunção do direito alemão desvincula o registro da existência de título causal ou da validade do negócio jurídico.

Por ocasião da evolução da regulação do tema no Brasil, ao longo dos séculos XIX e $\mathrm{XX}$, eram os sistemas alemão e francês os dois paradigmas. Assim, apesar das Ordenações Afonsinas considerarem, com base ainda no direito romano, a tradição como principal modo de aquisição e perda da propriedade, o Código Civil de 1916, elaborado no final do século anterior, seguindo o projeto de Clóvis Beviláqua, adotou o sistema de registro alemão, 
temperando-o quanto ao caráter absoluto do registro (a presunção do registro é relativa, admitindo retificações e cancelamentos). O código, desta forma, rompeu com o direito romano, abandonando a tradição como modo de aquisição e perda dos direitos reais e adota a imprescindibilidade da transcrição dos títulos no registro imobiliário, ainda que aceite, na via judicial ou na via administrativa, revisões e cancelamentos.

Assim, no sistema adotado no Brasil, somente com o registro ocorre a aquisição ou perda dos direitos reais sobre imóveis, ressalvando-se que o caráter relativo dessa transcrição correlaciona-se com a legitimidade do negócio causal do qual se origina o registro, como assevera Caramuru Afonso Francisco:

"ao contrário do direito alemão, onde a transcrição é fruto de um convênio entre as
partes, que a desvincula, por completo do negócio jurídico originário, gerador de
uma publicidade absoluta do registro, que passa a existir independentemente do
título de transferência, no Brasil a transcrição do título manteve-se ligada ao negócio
que a originou, dando ensejo a uma presunção juris tantum, uma vez que o próprio
adquirente que leva o negócio a registro" (FRANCISCO, 1999, 146).

Desde o Decreto 18.542, de 24 de dezembro de 1928 (art. 234), foi introduzido o princípio da continuidade:

Art. 234. Em qualquer caso não se poderá fazer transcripção ou inscripção sem prévio registro do título anterior, salvo se este não estivesse obrigado a registro, segundo o direito então vigente de modo a assegurar a continuidade do registro de cada predio, entendendo-se por disponibilidade a faculdade de registrar alienações ou onerações dependentes assim, da transcripção anterior.

Assim, no direito brasileiro, a propriedade imóvel se define, ordinariamente, pelo registro do título, independente até mesmo do modo de sua aquisição ter sido a usucapião (CC art. 1241, par. ún.) ou o próprio registro de outro título (CC, art. 1245). Seja qual for o modo de aquisição, o registro no cartório competente é o ato translativo da propriedade por excelência, como disciplina o Código Civil:

Art. 1.245. Transfere-se entre vivos a propriedade mediante o registro do título translativo no Registro de Imóveis.

$\S \mathbf{1}^{\mathbf{0}}$ Enquanto não se registrar o título translativo, o alienante continua a ser havido como dono do imóvel.

§ $\mathbf{2}^{\mathbf{0}}$ Enquanto não se promover, por meio de ação própria, a decretação de invalidade do registro, e o respectivo cancelamento, o adquirente continua a ser havido como dono do imóvel.

Art. 1.246. O registro é eficaz desde o momento em que se apresentar o título ao oficial do registro, e este o prenotar no protocolo.

A lei de registros públicos (Lei 6.015/73) confirma, inclusive, a obrigatoriedade dos atos de registro de sentenças declaratórias de usucapião e mesmo da legitimação da posse e de sua conversão em propriedade, elencando, em seu art. 167, quais os atos passíveis de registro, entre os quais se encontram tanto a compra e venda - como ato negocial declaratório - como a sentença declaratória de usucapião (ato constitutivo), como se infere dos ensinamentos de Miguel Maria de Serpa Lopes: 
“A expressão registro abrange a transcrição e a inscrição do direito anterior. Títulos ou atos constitutivos são p. ex., a escritura de compra e venda imobiliária e a sentença de reconhecimento de usucapião; títulos ou atos declaratórios são, p. ex., os julgados que partilharem imóveis, ou os demarcarem, bem como as escrituras de partilha amigável ou de demarcação; títulos ou atos extintivos são, p. ex., decisão judicial com trânsito em julgado, quitação, requerimento unânime das partes que tenham participado do ato registrado.

O efeito do registro pode ser a constituição, transferência, ou extinção do direito real, bem como a simples validade em relação a terceiros ou a sua melhor disponibilidade (p. ex., julgados que põem termo à indivisão)" (LOPES, 1996, 223)

Confirmando a correlação entre registro e propriedade, o artigo 167, prevê até mesmo o registro da compra e venda pura e da condicional e o art. 168 confirma que o registro engloba inscrição e transcrição abarcando a legislação civil:

Art. 167 - No Registro de Imóveis, além da matrícula, serão feitos.

I - o registro: [...]

29) da compra e venda pura e da condicional;

Art. 168 - Na designação genérica de registro, consideram-se englobadas a inscrição e a transcrição a que se referem as leis civis.

$\mathrm{O}$ art. 169 da Lei 6.015 estabelece a obrigatoriedade do registro dos atos e a competência - absoluta - do Cartório da situação do imóvel, exceto nas hipóteses que enumera:

Art. 169 - Todos os atos enumerados no art. 167 são obrigatórios e efetuar-se-ão no Cartório da situação do imóvel, salvo:

A lei de Registros Públicos explicita também (art. 172) que no Registro de Imóveis serão feitos, todos os registros e averbações dos títulos ou atos constitutivos, declaratórios, translativos e extintos de direitos reais sobre imóveis para constituição, transferência ou extinção, necessária ainda para sua validade em relação a terceiros ou para sua disponibilidade, não importando se sua origem for "mortis causa" ou ato "inter vivos":

Art. 172 - No Registro de Imóveis serão feitos, nos termos desta Lei, o registro e a averbação dos títulos ou atos constitutivos, declaratórios, translativos e extintos de direitos reais sobre imóveis reconhecidos em lei, "inter vivos" ou "mortis causa" quer para sua constituição, transferência e extinção, quer para sua validade em relação a terceiros, quer para a sua disponibilidade.

No sistema adotado, desta forma, o registro é essencial para a formação da cadeia sucessória dos bens imóveis e esta é necessária para o pleno e correto funcionamento do sistema cartorário, assim como para a caracterização da titularidade da propriedade no sistema pátrio. O modo de aquisição não se confunde com o direito em si de propriedade, como o modo de acesso (concurso público) não se confunde com o cargo público. A titularidade registral (de quem detém o registro) não representa uma controvérsia jurídica, pois proprietário é quem consta do registro.

Assim, verifica-se do tratamento jurídico da propriedade imobiliária no Brasil que o regime de direito privado (civil) das regras de aquisição, transferência e perda da propriedade, por fato ou ato jurídico, se associa a um regramento de direito público relacionado ao 
controle, pelo registro público, dos direitos reais imobiliários. Esta, não há controvérsia, é a regra geral, praticamente universal no direito pátrio. Apesar da forte e histórica tradição cartorária, o direito imobiliário, quanto ao loteamento urbano, tem desenvolvido tratamento distinto.

\section{3) A REGULAÇÃO DO LOTEAMENTO NO BRASIL.}

O loteamento é uma forma de fracionamento da propriedade imobiliária disciplinado por lei por meio do qual se realiza "o parcelamento do solo para fins urbanos" (Lei 6.766/79, art. $1^{\circ}$ ), identificado como a "subdivisão de gleba em lotes destinados a edificação, com abertura de novas vias de circulação, de logradouros públicos ou prolongamento, modificação ou ampliação das vias existentes" (Lei 6.766/79, art. $2^{\circ}, \S 1^{\circ}$ ) que pode somente pode ser realizado em "zonas urbanas, de expansão urbana ou de urbanização específica, assim definidas pelo plano diretor ou aprovadas por lei municipal" (Lei 6.766/79, art. $3^{\circ}$ ), sendo lote, por definição legal, "o terreno servido de infraestrutura básica cujas dimensões atendam aos índices urbanísticos definidos pelo plano diretor ou lei municipal para a zona em que se situe" (Lei 6.766/79, art. $2^{\circ}, \S 4^{\circ}$ ).

O loteamento deve atender aos requisitos do art. $4^{\circ}$ da Lei 6.766/79, incluindo o atendimento à legislação municipal que definirá "para cada zona em que se divida o território do Município, os usos permitidos e os índices urbanísticos de parcelamento e ocupação do solo" (Lei 6.766/79, art. $4^{\circ}, \S 1^{\circ}$ ) e regulará a destinação de parte da área para os equipamentos comunitários e públicos "de educação, cultura, saúde, lazer e similares" e "abastecimento de água, serviços de esgotos, energia elétrica, coletas de águas pluviais, rede telefônica e gás canalizado" (Lei 6.766/79, art. $4^{\circ}, \S 2^{\circ}$ e $5^{\circ}$, par. ún.) e estabelecerá, se for o caso, "a reserva de faixa non aedificandi destinada a equipamentos urbanos" (Lei 6.766/79, art. $\left.5^{\circ}\right)$.

O loteamento, desde o projeto, segue as diretrizes municipais (arts. $6^{\circ}$ a $9^{\circ}$ da Lei 6.766/79) e sua aprovação será da Prefeitura Municipal, ou dos Estados em situações especiais (arts. 10 a 16 da Lei 6.766/79), condição anterior ao seu registro (arts. 18 a 24 da Lei $6.766 / 79)$.

Observados requisitos e procedimentos legais, o Oficial de Registro de Imóveis fará “imediatamente o registro" e comunicará, por certidão, o registro à Prefeitura (art. 19, $\S \S 1^{\circ}$ e $5^{\circ}$ da Lei 6.766/79), passando, "desde a data de registro do loteamento [...] a integrar o domínio do Município as vias e praças, os espaços livres e as áreas destinadas a edifícios públicos e outros equipamentos urbanos, constantes do projeto e do memorial descritivo" 
(art. 22 da Lei 6.766/79). O Município, inclusive, poderá caso o loteamento implantado não tiver sido registrado, mediante a documentação prevista no dispositivo, requerer "o registro das áreas destinadas a uso público, que passarão dessa forma a integrar o seu domínio" (art. 22, par. ún. da Lei 6.766/79).

Estando regular o loteamento, os contratos que tenham por objeto os lotes, passam a transmitir direitos reais (art. 25 a 36 da Lei 6.766/79), dependendo qualquer alteração ou cancelamento parcial do loteamento registrado "de acordo entre o loteador e os adquirentes de lotes atingidos pela alteração, bem como da aprovação pela Prefeitura Municipal, ou do Distrito Federal quando for o caso" (art. 28 da Lei 6.766/79), resultando ao adquirente da propriedade loteada, qualquer que seja a forma da aquisição, suceder o transmitente "em todos os seus direitos e obrigações, ficando obrigado a respeitar os compromissos de compra e venda ou as promessas de cessão, em todas as suas cláusulas", ressalvado apenas "o direito do herdeiro ou legatário de renunciar à herança ou ao legado" (art. 29 da Lei 6.766/79).

Por estas razões, o processo de loteamento de imóveis, não obstante possa ser compreendido como um ato de exercício dos direitos de propriedade pelo titular, entre os quais os de dispor, usar e fruir do bem, sofre pela participação necessária e relevante da Administração Pública, não apenas influência de regras de direito público (no processo de aprovação do projeto), mas também de efeitos específicos com relação à transferência de direitos reais resultantes do próprio processo de fracionamento, constituindo até, em circunstâncias especiais, exceção às regras de transferência da propriedade imóvel.

\section{1) LOTEAMENTO E AQUISIÇÃO DA PROPRIEDADE PÚBLICA.}

$\mathrm{O}$ art. 22 da Lei 6.766/79 prevê a transferência para o domínio público das vias, praças, espaços livres e áreas destinadas a edifícios públicos e outros equipamentos urbanos constantes do projeto e do memorial descritivo, mesmo quando o loteamento não tiver sido registrado, como prevê o parágrafo único acrescido pela Lei 12.424/11:

Art. 22. Desde a data de registro do loteamento, passam a integrar o domínio do Município as vias e praças, os espaços livres e as áreas destinadas a edifícios públicos e outros equipamentos urbanos, constantes do projeto e do memorial descritivo.

Verifique-se que o artigo $6^{\circ}$ da Lei 12.424/11 alterou o parágrafo único do art. 22 da Lei no 6.766/79, permitindo até o registro das áreas destinadas a uso público mesmo quando o parcelamento do solo tiver sido implantado e não registrado. Antes mesmo da edição desta lei, já era efeito da inscrição do loteamento a inalienabilidade das áreas públicas, na forma do art. $3^{\circ}$ do Decreto $n^{\circ} 3.079 / 38$ e a doutrina especializada confirma:

Art. $3^{\circ}$ A inscrição torna inalienáveis, por qualquer título, as vias de comunicação e os espaços livres constantes do memorial e da planta. 
Assim, o simples registro do loteamento é suficiente para a transferência para o domínio público da propriedade dos bens que lhe pertencem, na forma do art. 22 da Lei 6.766/79, podendo o Município ainda, como visto, requerer diretamente o registro ao Cartório de Imóveis, caso o loteador não o faça, bastando apresentar a planta de parcelamento elaborada pelo loteador ou aprovada pelo Município, como prescreve o parágrafo único do artigo 22:

Parágrafo único. Na hipótese de parcelamento do solo implantado e não registrado, o Município poderá requerer, por meio da apresentação de planta de parcelamento elaborada pelo loteador ou aprovada pelo Município e de declaração de que o parcelamento se encontra implantado, o registro das áreas destinadas a uso público, que passarão dessa forma a integrar o seu domínio. (Inclusão lei $n^{\circ} 12.424$, de 2011)

O artigo 22 da Lei 6.766/79 mantém o registro como meio para a aquisição, mas a doutrina e a jurisprudência, neste caso específico, vão ainda mais adiante, admitindo que, dadas as particularidades do regime, mesmo sem o registro, para a Municipalidade adquirir a propriedade bastaria a aprovação do loteamento. A doutrina de Miguel Maria de Serpa Lopes confirma os efeitos do registro do loteamento acerca da constituição de cláusula de inalienabilidade sobre as áreas das vias públicas e os espaços livres:

"Em segundo lugar, produz outros efeitos legais constantes da lei do loteamento. Assim, a partir da inscrição, se tornam inalienáveis as vias de comunicação e os espaços livres constantes do memorial e da planta (art. $3^{\circ}$ do Decreto $\mathrm{n}^{\circ} 3079$, de 1938)" (LOPES, 1996, 223)

Neste sentido também a doutrina de Ricardo Marcondes Martins e Toshio Mukai e a jurisprudência do STF:

"Ao pleitear o registro do loteamento, o particular transfere, de plano, o domínio dessas áreas o Município. Elas passam a ser bens públicos e, pois, gozam de inalienabilidade, impenhorabilidade, imprescritibilidade. Não são, por força do último atributo, suscetíveis de usucapião. [...]

Daí o problema: o que ocorre quando o loteamento é implantado, mas não é registrado? Apesar da omissão legal, firmou-se o entendimento de que a transferência de domínio independe do registro, ocorre com a aprovação do projeto de loteamento. Assim, aprovado o loteamento, ocorre a transferência, ainda que o empreendedor não efetue o registro." (MARTINS, 2018, 729)

"Os arts. 17 e 43, não obstante a existência do art. 22, aproximam a questão da transferência das áreas públicas para o domínio do Município, da posição da jurisprudência, que construiu a tese do concurso voluntário, segundo a qual aquela transferência se dá independentemente do registro, bastando a intenção de destinar (do loteador) e o animus de aceitar da Prefeitura, geralmente expresso pela aprovação do loteamento.

Em suma, na pior das hipóteses, para a jurisprudência (que citaremos mais adiante), a passagem das áreas reservadas para uso público se dá com a aprovação do loteamento e não com o registro (concurso voluntário)." (MUKAI, 2006, 155)

(STF, 2 ${ }^{\circ}$ T., RE 84.327-SP, Rel. Min. Cordeiro Guerra, ac. un., de 28-9-75). Loteamento. Aprovado o arruamento, para urbanização de terrenos particulares, as áreas destinadas às vias e logradouros públicos passam automaticamente para o domínio público do município, independentemente de título aquisitivo e transcrição, visto que o efeito jurídico do arruamento é, exatamente, o de transformar o domínio particular em domínio público, para uso comum do povo. Não tem o loteador infringente do Dec.-lei no 7 58/1937 mais direitos que o loteador a ele obediente. 
A jurisprudência vai além: com a aprovação da planta pela loteadora e sua aceitação pela Municipalidade, ocorre a transferência de domínio, ainda que o condomínio não venha a ser executado no plano fático.

(TJ-SP, Apelação Cível no 159.196.5/7-00. Rel. Des. Adauto Luiz da Silva. Julg. 17.5.04) É de se ver que, em se tratando de áreas destinadas para vias e logradouros públicos, referentes a loteamentos, objeto de pedido de aprovação pelo loteador à Municipalidade, com aprovação por esta, a transferência de tais áreas do domínio particular para o público ocorre com a simples apresentação, para aprovação da planta de loteamento, pela loteadora, e aceitação do pedido pela Municipalidade, independentemente de título aquisitivo e transcrição, bem como efetiva consumação fática do loteamento, com a realização as obras necessárias.

Não deve, porém, causar maior perplexidade a concepção da transferência da propriedade para o Município, mesmo sem a implantação física do loteamento, pois faz parte do processo de aprovação do fracionamento a apresentação do "competente instrumento de garantia para a execução das obras" (art. 18, V, da Lei 6.766/79), garantia esta que, via de regra, é feita pelo caucionamento de quantidade de lotes suficientes para cobrir as despesas com a execução das obras necessárias à implantação do loteamento.

Assim, verifica-se que a aprovação do projeto de fracionamento pela Municipalidade, mesmo na hipótese do mesmo não vir a ser registrado no Cartório de Imóveis Competentes nem implantado, implica na transferência de direitos reais para o Poder Público em relação às áreas públicas e aos equipamentos urbanos, comunitários e públicos, cabendo à Municipalidade, no caso do loteador não executar as obras, acionar as garantias prestadas e realizar a obra.

Tal situação, indubitavelmente, corresponde a uma exceção ao regime jurídico da propriedade imóvel no Brasil.

\section{2) LOTEAMENTO E AQUISIÇÃO DE DIREITOS REAIS PELO PARTICULAR.}

Com o registro do loteamento no Cartório de Imóveis, além do destaque da parcela correspondente as áreas públicas e aos equipamentos urbanos, comunitários ou públicos, ocorre, de logo, o fracionamento do imóvel loteado, passando a existir no plano do direito imobiliário, vários imóveis (lotes) em unidades distintas sobre os quais já incidem direitos reais (como a caução de lotes para garantir a execução das obras).

A questão, porém, é analisar se o particular adquirente de um loteamento aprovado pela Prefeitura, não registrado ou não implantado, também adquire, como o Poder Público, a propriedade, algum tipo de direito real, ou detém apenas direitos obrigacionais resolúveis em perdas e danos.

A primeira evidência da existência de uma situação jurídica especial é o regime de condições para o cancelamento do loteamento. O loteador somente pode cancelar, com 
anuência da Prefeitura, se nenhum lote tiver sido objeto de contrato (art. 23, II, da Lei 6.766/79) ou, a requerimento do loteador e de todos os adquirentes de lotes, também com anuência do Poder Público (art. 23, III, da Lei 6.766/79). Atribuir apenas efeitos obrigacionais aos contratos firmados tendo os lotes por objeto, implicaria em manter o direito do loteador (proprietário) dispor livremente do bem imóvel de sua titularidade, reparando, se fosse o caso, pela via das perdas e danos eventuais inadimplementos de obrigações.

Quando o dispositivo invocado condiciona a disposição do proprietário à inexistência de contrato ou a requerimento conjunto pelos adquirentes, reconhece que a contratação afeta reduzindo - o direito de propriedade do titular.

$\mathrm{O}$ art. 25 da Lei 6.766/79 também prevê que "são irretratáveis os compromissos de compra e venda, cessões e promessas de cessão, os que atribuam direito a adjudicação compulsória e, estando registrados, confiram direito real oponível a terceiros", reconhecendo o direito real dos instrumentos de transação registrados no Cartório. O art. 26 admite sua confecção por escritura pública, assim como o arquivo para anotações devidas do instrumento no registro imobiliário $\left(\$ 1^{\circ}\right.$ do art. 26$)$.

$\mathrm{O} \S 6^{\circ}$ do art. 26 estipula expressamente que "os compromissos de compra e venda, as cessões e as promessas de cessão valerão como título para o registro da propriedade do lote adquirido, quando acompanhados da respectiva prova de quitação". Esta previsão de eficácia translativa de direito real de propriedade (incluída pela Lei 9.785/99), portanto, antecedeu a dos artigos 1.417 e 1.418 do Código Civil, assim como: a) a Súmula 239 do STJ (Súmula 239 - O direito à adjudicação compulsória não se condiciona ao registro do compromisso de compra e venda no cartório de imóveis), de 28/06/2000; b) o Enunciado 95 do CEJ (Enunciado 95 - O direito à adjudicação compulsória (art. 1.418 do novo Código Civil), quando exercido em face do promitente vendedor, não se condiciona ao registro da promessa de compra e venda no cartório de registro imobiliário (Súmula n. 239 do STJ)); c) o Enunciado 253 do CEJ (Enunciado 253 - O promitente comprador, titular de direito real (art. 1.417), tem a faculdade de reivindicar de terceiro o imóvel prometido à venda.

Este entendimento alinha-se com a normatização estabelecida desde o Decreto-Lei 58/37, que, em seu art. 16, com a redação dada pela Lei 6.014/73 já previa a possibilidade de adjudicação compulsória no caso da conclusão do pagamento integral do preço (art. 15, do DL 58/37). 
Desde então, e nas hipóteses aceitas, o particular torna-se detentor de direito real apenas com o pagamento integral do preço, fato que tem sido utilizado como divisor de águas entre o direito obrigacional e o real, em situação diversa da do Poder Público.

O principal nó é a compreensão de que os contratos dos adquirentes, antes da quitação, não lhe conferem qualquer direito real, motivo pelo qual, quando, por exemplo, o loteador suspende as obras, a recomendação mais usual é exatamente não investir mais para não perder.

É este nó górdio que se pretende desatar a partir da análise das disposições atualmente aplicáveis ao loteamento, que, em conjunto com os precedentes, podem viabilizar a construção de uma solução diversa, fundada em direitos reais surgidos do contrato de aquisição de loteamento por particular.

A própria Lei 6.766/79 (art. 23, II e III), condiciona o cancelamento de registro do loteamento ou a inexistência de contrato ou, caso tenha sido celebrado algum, ao requerimento ser formulado por todos os adquirentes de lotes. O direito de consentir não está condicionado à quitação do preço, mas apenas à existência do contrato. Isso significa, em termos práticos, que a contratação da compra e venda de um lote, por si, é suficiente para conferir ao adquirente um direito igual ao do loteador (proprietário) em relação ao cancelamento do loteamento. Observe-se, neste caso, que a discordância de apenas um adquirente, independentemente de ter quitado a compra do lote, é suficiente para inviabilizar o cancelamento. Para começar, qual seria a natureza deste direito, obrigacional ou real?

Direito obrigacional resulta de uma relação jurídica e vincula seus sujeitos, resolvendo-se pelo adimplemento forçado, quando possível, ou por perdas e danos, quando não. O direito real se notabiliza por ser oponível erga omnes e projetar-se sobre a coisa. A seguir a definição clássica, em sua síntese, é preciso concluir que os incisos do art. 23 da Lei 6.766/79 reconhecem ao adquirente, por força do contrato, um direito real, inclusive e especialmente por ser oponível contra todos e constituir-se em relação ao bem em si. De fato, o comprador pode ter celebrado negócio com apenas um lote, que, naturalmente, representa uma fração pequena de toda a propriedade, seja em relação com as demais áreas privadas, seja em relação com a área pública, mas, por força deste vínculo contratual tem o direito de imedir o cancelamento do loteamento por ato próprio de exclusiva vontade.

Deve-se, portanto, concluir que, mesmo antes da quitação, com apenas a celebração de contrato tendo por objeto lotes, o adquirente passa a deter direito de natureza real, oponível erga omnes, que tutela o direito à percepção de seu próprio lote, acrescido das áreas comuns e 
equipamentos previstos no projeto, pois, ainda que tenha adquirido uma unidade, faz jus à receber a sua parte acrescida de tudo o que está no projeto aprovado, incluindo arruamento, equipamentos, etc. Como adverte Toshio Mukai, a propriedade, ao ser parcelada, passa a ser acrescida:"A propriedade loteada significa a gleba parcelada acrescida dos direitos e obrigações do parcelador exsurgentes do processo de parcelamento." (MUKAI, 2006, p. 157).

A partir da conclusão de que, nos termos dos incisos II e III do art. 23 da Lei 6.766/79, os compradores adquirem direitos de natureza real, se pretende projetar o alcance destes direitos em relação ao patrimônio jurídico dos envolvidos (loteador, particulares e Poder Público).

Para tal desiderato, observe-se, ainda, que, na forma do art. 36 da Lei 6.766/79, exceto por decisão judicial, o registro do compromisso, cessão ou promessa de cessão só poderá ser cancelado a requerimento conjunto das partes contratantes ou quando houver rescisão comprovada do contrato, sendo que esta deve respeitar o procedimento previstos nos artigos 32 a 35 da referida lei.

Contribui para reforçar a titularidade do adquirente de direitos sobre o bem a possibilidade de transferência do contrato por ato unilateral (art. 31, e seus $\S \S$, da Lei 6.766/79), sem a anuência do loteador, a confirmar a eficácia do ato de alienação.

A transferência por ato unilateral "simples trespasse, lançado no verso das vias em poder das partes, ou por instrumento em separado, declarando-se o número do registro do loteamento, o valor da cessão e a qualificação do cessionário, para o devido registro" (art. 31) implica em reconhecer que o loteador não tem mais a disponibilidade do bem, que já a alienou ao comprador, mesmo que a transferência da propriedade não tenha ocorrido. Observe-se que o loteador precisa ser apenas notificado (por qualquer das partes ou pelo Cartório), e com intuito de mera cientificação para a produção de efeitos, ou seja, já reconhecida a validade e eficácia entre partes, resta a eficácia para o loteador que, nitidamente, ocupa a posição de terceiro obrigado pelo negócio jurídico.

De fato, se o comprador pode, sem envolver o loteador, transferir o contrato de aquisição do lote com todos os encargos e direitos, a disponibilidade do bem (ainda que desta fração) pertence ao seu patrimônio jurídico, tendo sido retirada do patrimônio do loteador. Orlando Gomes esclarece:

“A alienação é ato pelo qual o proprietário, por vontade própria, transmite a outrem o seu direito sobre a coisa. $O$ direito de propriedade perde-se, pela alienação, para o transmitente. Ela é, portanto, forma de extinção subjetiva da propriedade. A alienação, por definição, há de ser voluntária. Segundo ALDO 
BOZZI, os elementos que concorrem para formar o conceito de alienação se resumem nos seguintes: a) o destaque voluntário de um direito da pessoa do titular; b) a manifestação de vontade do mesmo titular dirigida no sentido de que o direito seja atribuído a outro sujeito; c) uma correspondente vontade de aceitação da parte deste sujeito; d) um nexo de causalidade ou nexo genérico entre perda e aquisição do direito; e) a contemporaneidade entre perda e aquisição e a dependência de um e outro fato da mesma causa jurídica." (negritos acrescidos) (GOMES, p. 258).

Mesmo que Orlando Gomes entendesse, à luz do Código Civil, que a eficácia da alienação em relação aos bens imóveis estaria ordinariamente dependente da transcrição do título transmissivo (GOMES, 260), o que, no caso do loteamento é objeto de tratamento legislativo específico e diverso, fica claro que a alienação importa em perda da disponibilidade. É exatamente o que se quer sustentar aqui.

Ainda a confirmar o plexo de obrigações surgidas com a aprovação do loteamento, cabe recordar que, além dos adquirentes, a Prefeitura e o Ministério Público (art. 38, §2º da Lei 6.766/79) podem promover a notificação do loteador para registro do desmembramento ou loteamento, irregularidade que, enquanto perdurar, autoriza o comprador a suspender os pagamentos (art. 38 da Lei 6.766/79). A Prefeitura poderia também regulariza o registro ( $\$ 5^{\circ}$ do art. 38 da Lei 6.766/79). O fundamento da regularização do loteamento pela Prefeitura, em sintonia com os aspectos urbanísticos anteriormente mencionados, é expresso na legislação:

Art. 40. A Prefeitura Municipal, ou o Distrito Federal quando for o caso, se desatendida pelo loteador a notificação, poderá regularizar loteamento ou desmembramento não autorizado ou executado sem observância das determinações do ato administrativo de licença, para evitar lesão aos seus padrões de desenvolvimento urbano e na defesa dos direitos dos adquirentes de lotes.

Se a motivação vinculada ao interesse público é evidente, o procedimento adotado pelos parágrafos do mesmo artigo 40 da Lei 6.766/97 também trazem implicações jurídicas:

$\$ \mathbf{1}^{\circ}$ A Prefeitura Municipal, ou o Distrito Federal quando for o caso, que promover a regularização, na forma deste artigo, obterá judicialmente o levantamento das prestações depositadas, com os respectivos acréscimos de correção monetária e juros, nos termos do $\S 1^{\circ}$ do art. 38 desta Lei, a título de ressarcimento das importâncias despendidas com equipamentos urbanos ou expropriações necessárias para regularizar o loteamento ou desmembramento.

$\$ 2^{\mathbf{0}}$ As importâncias despendidas pela Prefeitura Municipal, ou pelo Distrito Federal quando for o caso, para regularizar o loteamento ou desmembramento, caso não sejam integralmente ressarcidas conforme o disposto no parágrafo anterior, serão exigidas na parte faltante do loteador, aplicando-se o disposto no art. 47 desta Lei.

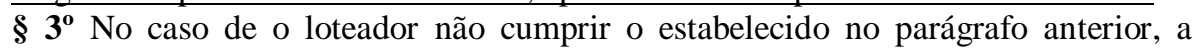
Prefeitura Municipal, ou o Distrito Federal quando for o caso, poderá receber as prestações dos adquirentes, até o valor devido.

A transcrição da propriedade, neste caso, mais uma vez ficará condicionada à quitação do preço, nos termos do art. 41 da Lei 6.766/79, mas isto, como se argumentará adiante, não altera a natureza do direito dos adquirentes.

Isto porque a regra do art. 41, que protege o equilíbrio econômico e financeiro do erário em relação aos custos que vier a assumir para implantar o loteamento, não altera o alcance real do direito do adquirente, como se infere do texto do art. 43 da Lei 6.766/79: 
Art. 43. Ocorrendo a execução de loteamento não aprovado, a destinação de áreas públicas exigidas no inciso I do art. $4^{\circ}$ desta Lei não se poderá alterar sem prejuízo da aplicação das sanções administrativas, civis e criminais previstas.

Parágrafo único. Neste caso, o loteador ressarcirá a Prefeitura Municipal ou o Distrito Federal quando for o caso, em pecúnia ou em área equivalente, no dobro da diferença entre o total das áreas públicas exigidas e as efetivamente destinadas.

Há mais um interesse juridicamente reconhecido e tutelado dos adquirentes que revela a natureza real do direito incorporado ao seu patrimônio com a celebração do contrato de compra do lote, o direito de impedir obras irregulares:

Art. 45. O loteador, ainda que já tenha vendido todos os lotes, ou os vizinhos, são partes legítimas para promover ação destinada a impedir construção em desacordo com restrições legais ou contratuais.

A literalidade do texto do art. 45 da Lei 6.766/79 deixa patente que se incorporam ao patrimônio jurídico do adquirente, pelo contrato, não apenas as restrições legais (direito adquirido), mas também as contratuais (ato jurídico perfeito), evidenciando que, por meio do contrato, com seus anexos necessários, inclusive restrições urbanísticas (art. 26, VII), são transferidos direitos reais inclusive sobre a propriedade alheia. Com efeito, o direito de opor contra terceiros restrições legais decorre da própria incidência da regra jurídica ao caso concreto, mas o direito de opor limitações sobre o direito de propriedade que decorrem de cláusulas contratuais, notadamente quanto a terceiros (um adquirente em relação a outro adquirente com o qual não pactuou diretamente) denota a presença no contrato de loteamento de direitos reais, direitos sobre a propriedade e oponíveis erga omnes,

O caráter público, assim como a relevância do interesse coletivo envolvido, no fracionamento do solo urbano por meio de loteamento é evidenciado pelo Capítulo IX da Lei 6.766/79 que reúne as disposições penais e caracteriza como crime contra a Administração pública dar início, de qualquer modo, ou efetuar loteamento ou desmembramento do solo para fins urbanos, sem autorização do órgão público competente, ou em desacordo com as disposições da Lei 6.766/79 ou das normas pertinentes do Distrito Federal, Estados e Municípios, ou sem observância das determinações constantes do ato administrativo de licença, assim como fazer ou veicular em proposta, contrato, prospecto ou comunicação ao público ou a interessados, afirmação falsa sobre a legalidade de loteamento ou desmembramento do solo para fins urbanos, ou ocultar fraudulentamente fato a ele relativo.

Por tudo o quanto já exposto, é possível deduzir que celebrado o contrato tendo por objeto um loteamento aprovado no ente federado competente, nos termos da própria Lei 6.766/79 o adquirente tem, mesmo sem seu registro, o direito de: a) se opor ao cancelamento do loteamento; b) transferência da propriedade livre e desembaraçada (se não pactuar qualquer garantia real) após a quitação; c) impedir construções de terceiro em desacordo com 
restrições legais e contratuais; d) transferir unilateralmente o contrato, com os direitos que lhe são inerentes; e) obstaculizar a modificação do projeto do loteamento, inclusive para alterar as áreas comuns. Com o registro, passaria a ter direitos reais oponíveis contra terceiros e, com a prova da quitação, o direito de transferir a propriedade ou de adjudica-la compulsoriamente.

Apesar destes reconhecidos direitos e da natureza dos mesmos, momo visto, assentou a compreensão de que há apenas direitos obrigacionais antes do pagamento do preço, fato que tem sido utilizado como divisor de águas entre o direito obrigacional e o real, em aparente assimetria com o Poder Público.

Se poderia dizer que inexiste tal assimetria, pois, sendo a transferência dos bens públicos gratuita, o Município estaria quite com relação a qualquer contrapartida. Todavia, o Ente Público não apenas recebe, com a aprovação do projeto, a transferência das áreas que lhe cabem, como ainda a garantia por parte do loteador suficiente para a execução das obras. Esta circunstância significa, de um lado, que o Poder Público recebe seus bens e condição para, mesmo sem o concurso do loteador, torna-los realidade (com as benfeitorias necessárias).

Esta condição especial, todavia, não pode ser concebida como graciosa, não diante da importância que a concretização do contrato tem neste contexto, pois o papel da Administração Pública não se resume a assegurar o cumprimento das normas urbanísticas, mas em dar efetividade ao planejamento urbano feito e aprovado, notadamente quando envolve terceiros de boa-fé.

Com efeito, o regramento jurídico de utilização e parcelamento do solo urbano é um dos principais mecanismos de estruturação urbanística das cidades, seja no plano normativo, seja no plano prático, pois é determinante para o desenvolvimento dos espaços urbanos, orientando as políticas públicas e os investimentos particulares (de loteadores e de adquirentes), influenciando, diretamente, a ordenação do crescimento e afetando a realidade física das cidades, com reflexos sobre todos os aspectos determinantes para a qualificação da vida nos aglomerados populacionais.

"Portanto, o planejamento urbano é o principal mecanismo que garante ao Estado o
poder de interferir, embora com limites, no modo pelo qual a iniciativa privada e a
lógica mercadológica pretendem atuar na construção e exploração (econômica e
social) dos espaços urbanos.” (TAVARES, 2018, 502)
"O Direito Urbanístico é uma ciência que tem por finalidade a organização do
território. Seu objeto é a transformação e o desenvolvimento das localidades, dando
o máximo de bem-estar aos cidadãos, conservando, preservando e mantendo valores
e bens comunitários que são imprescindíveis para garantir a habitação, o trabalho, a
recreação e a melhor circulação aos habitantes." (WERNER, 1998, 301/302)

A qualidade de vida de todos os cidadãos, os padrões ambientais, ao conforto visual e estético do espaço urbano, em resumo, a própria experiência de residir em um centro urbano 
são impactados pelas normas urbanísticas como um todo, e o regramento da utilização e do parcelamento do solo não é exceção. Hely Lopes Meirelles, André Ramos Tavares e Patrícia Ulson Pizarro Werner concordam:

O controle do uso do solo urbano apresenta-se como das mais prementes necessidades em nossos dias, em que o fenômeno da urbanização dominou todos os povos e degradou as cidades mais humanas, dificultando a vida de seus moradores pela redução dos espaços habitáveis, pela deficiência de transportes coletivos, pela insuficiência dos equipamentos comunitários, pela promiscuidade do comércio e da indústria em áreas de residência e lazer. (MEIRELLES, 2006, 552)

"O "pleno desenvolvimento das funções sociais da cidade" consiste em moldar o espaço urbano a fim de assegurar que este propicie a consecução do direito ao meio ambiente saudável, à moradia, ao lazer, enfim, dos direitos socioeconômicos. [...]

Sendo o direito amplo à cidade uma norma-dever, há de ser considerado como peça essencial para o adequado desenvolvimento urbano, o que implica considerar o desenvolvimento da própria cidadania" (TAVARES, 2018, 502)

“Tendo o Direito Urbanístico a função precípua de ordenar espaços habitáveis, buscando a realização do bem-estar social através do cumprimento das regras constitucionais da função social da propriedade, as licenças urbanísticas devem trazer essa finalidade em sua essência.

Deve-se condicionar a necessidade do requerimento da licença urbanística a busca da função social da propriedade e, consequentemente, o tão almejado bem-estar dos habitantes." (WERNER, 1998, 312)

Sem retirar a importância de cada um dos microssistemas jurídicos inseridos no direito urbanístico, e focando especificamente na utilização e no parcelamento do solo, ressalta-se suma importância sobre a estruturação da cidade em relação à suas unidades imobiliárias. A importância deste aspecto resulta de que nestas unidades é que os cidadãos percebem e sentem, mais direta e pessoalmente, sua experiência no ambiente das cidades.

Com efeito, as regras de parcelamento afetarão as unidades residenciais, comerciais e públicas, exatamente os locais nos quais aqueles que vivem ou convivem na cidade experenciarão, no plano individual, a vida naquela localidade. Definidas, portanto, as regras de utilização e parcelamento do solo, elas passam a afetar diretamente o desenvolvimento da comunidade. Dentre as regras de utilização e parcelamento estão aquelas relativas à instituição de loteamentos, com reflexos sobre a iniciativa privada e sobre o Poder Público.

O loteamento, assim, embora envolva diretamente o loteador e os adquirentes de área (pública ou privada), afeta também a sociedade na qual está inserida, tanto no seu sucesso, quanto, às vezes ainda mais, no seu fracasso. A não instalação de um grande loteamento tem efeitos deletérios para a própria área, para a economia local e, em casos mais graves, para o próprio desenvolvimento do município, segundo o planejamento feito.

Encontrar caminho para a efetivação do direito dos adquirentes, quando a construção do loteamento está ameaçada, desta maneira, extrapola os direitos individuais dos compradores. E, infelizmente, é comum em situações de interrupção ou término das obras que os adquirentes, pela análise comum de sua situação jurídica, entrem em um círculo vicioso 
fatal. A suspensão das obras afeta a confiança no loteador, o pagamento das prestações (a maioria das aquisições é a prazo) cessam, as dificuldades financeiras do loteador aumentam e, quase sempre, o resultado é o mesmo: área abandonada, com grandes chances de degradação, loteador sem recursos para executar a obra e/ou devolver o quanto recebido dos adquirentes, compradores sem o imóvel e sem chances de recuperar o dinheiro.

Por estas razões que, com base nos outros direitos de natureza real, é que se pretende sustentar que, o adquirente de um lote de loteamento aprovado pela Prefeitura tem o direito real à propriedade, sujeito apenas à condição, para sua transferência livre e desembaraçada, de quitar o preço, pois, conforme os ensinamentos de Orlando Gomes, em sua obra Direitos Reais, a alienação é ato volitivo do proprietário por meio do qual "transmite a outrem o seu direito sobre a coisa" (fls. 258) de forma que "o direito de propriedade perde-se, pela alienação, para o transmitente" (fls. 258), sendo esta uma "forma de extinção subjetiva da propriedade" (fls. 258). Este direito real "ao lote", desta maneira, além dos aspectos já desenvolvidos, resultantes diretamente do texto legal, deve incluir o direito à exigir do loteador ou da administração pública a execução das obras em conformidade com o projeto aprovado, não sendo outro o objetivo das garantias prestadas pelo loteador para a aprovação do loteamento, nem do procedimento previsto na própria legislação para assunção das obrigações pelo Ente Federado.

Não apenas pelos reflexos urbanísticos, sociais, econômicos e financeiros da inconclusão das obras do loteamento, mas em função da legislação condicionar a aprovação do projeto à apresentação de garantias de sua execução em favor da Administração Pública e, em especial, pelos efeitos deletérios também sobre o direito de propriedade é que, caso a obra não seja concluída pelo loteador, cabe à Administração Pública, executando as garantias, entregar à sociedade e ao próprio poder público as áreas que são suas por direito.

Com efeito, considerando que a mera aprovação do loteamento confere direitos reais à própria Administração Pública, a presença de patrimônio público em risco, via de regra associado a prestação de serviços públicos essenciais (como saúde e educação) ou interesses coletivos relevantes (como mobilidade urbana), já seria suficiente para concluir ser dever do Estado concluir as obras do loteamento executando as garantias e obtendo dos loteadores, se for o caso ressarcimento se estas não forem suficientes para cobrir os gastos.

Mas é também necessário reconhecer a existência de direitos reais dos adquirentes, que, nesta qualidade não podem ser resolvidos em perdas e danos, que oponíveis erga omnes 
também o são contra o Poder Público, inclusive para exigir a finalização das obras necessárias para que o bem de sua titularidade lhe seja entregue.

Concorre neste sentido o fato de que o direito imobiliário brasileiro empresta ao registro público o controle da propriedade, de forma que, feito o registro do loteamento aprovado nas instâncias administrativas competentes, no cartório territorialmente encarregado, pelo loteador ou pela Administração Pública (até o adquirente teria legitimidade para fazê-lo), passam a existir (com as correspondentes matrículas) os imóveis públicos e particulares fracionados, em detrimento do imóvel (gleba) anterior.

O princípio da continuidade do registro veda a dissociação dos dados cadastrais da realidade, o que fatalmente viria a ocorrer com o registro no cartório de imóveis de lotes inexistentes, equipamentos e áreas públicas virtuais. Deve-se, assim, compreender que ao celebrar o contrato de aquisição de um lote aprovado pela Administração Pública o comprador adquire do loteador direitos reais que o autorizam não apenas a se opor contra atos de terceiros que violem seus direitos, como também a exigir a satisfação de seus direitos de natureza real, inclusive contra o Poder Público que recebe garantias exatamente para fazer frente a eventuais despesas nas quais tenha que incorrer. A assinatura confere direitos (direito adquirido) que devem respeitar os limites do negócio pactuado à luz do ordenamento vigente (ato jurídico perfeito).

$\mathrm{Na}$ conceituação de direito adquirido prevalece o entendimento em torno da afirmação de surgir o direito adquirido quando o sujeito ativo reúne todas as condições suficientes e necessárias para incorporar o direito em questão ao seu patrimônio jurídico, de forma a poder exercê-lo de acordo com sua conveniência, ou quando ocorrerem o termo ou a condição (inclusive legal) que sobrestem seu exercício. A Lei de Introdução às Normas do Direito Brasileiro (nova designação da conhecida LICC - Lei de Introdução ao Código Civil Brasileiro) define, in verbis, o ato jurídico perfeito e o direito adquirido:

Art. $6^{\circ}$ A Lei em vigor terá efeito imediato e geral, respeitados o ato jurídico perfeito, o direito adquirido e a coisa julgada.

$\S 1^{\circ}$ Reputa-se ato jurídico perfeito o já consumado segundo a lei vigente ao tempo em que se efetuou.

$\$ \mathbf{2}^{\mathbf{0}}$ Consideram-se adquiridos assim os direitos que o seu titular, ou alguém por ele, possa exercer, como aqueles cujo começo do exercício tenha termo pré-fixo, ou condição pré-estabelecida inalterável, a arbítrio de outrem.

O pensamento da doutrina brasileira a respeito do assunto está bem representado na lição de CAIO MÁRIO DA SILVA PEREIRA (1961, 125):

"Direito adquirido, in genere, abrange os direitos que o seu titular ou alguém por ele possa exercer, como aqueles cujo começo de exercício tenha termo pré-fixo ou condição preestabelecida, inalterável ao arbítrio de outrem. São os direitos definitivamente incorporados ao patrimônio do seu titular, sejam os já realizados, 
sejam os que simplesmente dependem de um prazo para seu exercício, sejam ainda os subordinados a uma condição inalterável ao arbítrio de outrem. A lei nova não pode atingi-los, sem retroatividade."

A suficiência para a aquisição do direito do preenchimento dos requisitos previsto na norma hipotética é unânime na doutrina, assim como seu caráter patrimonial, mesmo quando envolve relações de direito público, como leciona Hugo de Brito Machado:

"Direito adquirido é, como todo direito, um efeito da incidência da norma sobre o
seu suporte fático. Sua existência, pois, pressupõe consumado esteja o fato que
participa de sua formação. Particulariza-se, porém, pelo conteúdo patrimonial que
lhe confere especificidade.
O ter conteúdo patrimonial, contudo, não significa que não possa residir em relações
de direito público, como as que se estabelecem entre o contribuinte e o fisco, ou
entre o servidor e a Administração". (MACHADO, 1985, 20).

A incorporação definitiva ao patrimônio ou à personalidade do sujeito é também elemento constante do conceito de direito adquirido, assim como o fato de não estar sujeito ao arbítrio de outrem, como releva Luiz Antônio Nunes e Paulo Modesto:

"Direito adquirido, como o nome sugere, é o que já se incorporou definitivamente ao patrimônio e/ou à personalidade do sujeito de direito. $\mathrm{O}$ direito torna-se adquirido por consequência concreta e direta da norma jurídica ou pela ocorrência, em conexão com a imputação normativa, de fato idôneo, que gera a incorporação ao patrimônio e/ou à personalidade do sujeito." (NUNES, 1996, 170).

"..., possa exercer, como aqueles cujo começo de exercício tenha termo prefixo, ou condição preestabelecida inalterável, a arbítrio de outrem." (MODESTO, 1999, 24)

O direito adquirido, por consequência, é aquele que deriva da incidência da norma geral hipotética, após a satisfação de todos os seus requisitos, transformando-se em norma individual em decorrência da previsão legislativa do fato - ou ato - ser suficiente para a geração de efeitos jurídicos na esfera de interesses juridicamente tutelados do sujeito ativo. Inexiste dúvida, como visto anteriormente, acerca da aquisição de direitos reais por força da celebração do contrato, posterior ao fracionamento nos termos do projeto aprovado. Neste sentido os ensinamentos de Limongi França mencionados por Maria Helena Diniz acerca do direito adquirido: "Na lição de R. Limongi França o direito adquirido é "a consequência de uma lei, por via direta ou por intermédio de fato idôneo; consequência que, tendo passado a integrar o patrimônio material ou moral do sujeito" (DINIZ, 1994, 182).

O processo de loteamento aprovado também produz efeitos jurídicos que lhe são próprios, pois trata-se de ato jurídico perfeito, tutelado como norma individual aderente ao patrimônio jurídico do sujeito, com a mesma proteção do direito adquirido até contra modificação legislativa. $\mathrm{O}$ ato jurídico perfeito refere-se à situação consumada fruto de manifestação de vontade nos termos e formas admitidos como necessários e suficientes pela legislação de então, que, desta forma, gera situação jurídica incorporada ao patrimônio jurídico ou à personalidade do respectivo titular pela circunstância do ato praticado ter atendido aos requisitos normativos vigentes à época para ter plena validade e eficácia jurídica. 
O contrato celebrado sob a égide da Lei antiga, assume o caráter actus perfectus, ficando subordinado á lei ao tempo de sua instituição, ou, como adverte Celso Ribeiro Bastos, "é ato jurídico perfeito aquele que se aperfeiçoou, que reuniu todos os elementos necessários à sua formação, debaixo da lei velha" (2000, 220). O princípio "tradicional do constitucionalismo brasileiro" (SOARES, 2002, 174), presente na primeira das constituições (BASTOS, 2000, 215) remonta a famoso enunciado romanístico do Imperador Teodósio do ano de 440 que vetava a revogação de facta praeterita pela lei posterior.

"Em termos efetivos, e consoante a legislação em vigor que regula o instituto, por
efeito, denomina-se direito adquirido todo o direito que, derivado do ato jurídico
perfeito ou da coisa julgada, já tenha sido efetivamente incorporado ao patrimônio
do titular e, por esta razão - independente do prévio e anterior pleno exercício
(conceito próprio do direito exaurido) - não mais pode ser subtraído do mesmo"
(FRIEDE, 1999, 156).

Como leciona José Cretella Júnior (1998, 460): "Na expressão “ato jurídico perfeito" o vocábulo "perfeito" tem o sentido de "acabado", "que completou todo o ciclo de formação", "que preencheu todos os requisitos exigidos pela lei”. Neste ponto, releva recordar os ensinamentos de José Afonso da Silva, em sua clássica obra sobre a aplicabilidade das normas constitucionais, quando incluiu a garantia do inciso XXXVI do art. $5^{\circ}$ entre as normas constitucionais de eficácia plena, ainda que destinada aos legisladores como regra de competência negativa fixada pelo Legislador Constituinte Originário (SILVA, 2002, p. 98). PONTES DE MIRANDA concordava: “a lei nova não pode retirar do mundo jurídico o ato jurídico perfeito, nem alterá-lo a seu talante" (1987, p. 101).

Titulares de direitos de natureza real, os adquirentes podem, portanto, promover ações contra o loteador ou o próprio Poder Público formulando pedido no Poder Judiciário destinado a satisfazer o direito em si, ou seja, a construção e entrega do loteamento concluído, única forma de dar efetividade ao ordenamento na forma vaticinada no CPC ( $\operatorname{art} .8^{\circ}$ ).

\section{4) CONCLUSÕES}

1) O sistema brasileiro de controle da propriedade imobiliária é o registral.

2) O regramento do loteamento urbano pela Lei 6.766/79 confere direitos reais à Administração Pública e aos adquirentes de lotes, mesmo antes da quitação integral do preço.

3) Em função dos direitos reais decorrentes da assinatura de contrato para a aquisição dos lotes, os adquirentes, além dos direitos diretamente assegurados pela Lei 6.766/79, oponíveis erga omnes contra terceiros, teriam também o direito de exigir do loteador ou da própria Administração Pública, inclusive judicialmente, a efetiva implantação do loteamento, valendo-se das garantias previstas na legislação para este fim, como forma de respeitar os 
direitos adquiridos dos compradores e os atos jurídicos perfeitos representados pela aprovação do projeto de loteamento e pelos contratos celebrados entre os particulares.

\section{REFERÊNCIAS}

BASTOS, Celso Ribeiro. Curso de direito constitucional. 21 a ed. São Paulo: Saraiva, 2000.

BRITTO, Carlos Ayres, PONTES FILHO, Valmir. Direito Adquirido contra as Emendas

Constitucionais. In: Revista de Direito Administrativo, v. 202 . Rio de Janeiro: Renovar, 1995

COSTA, Célio Silva. A Interpretação Constitucional e os Direitos e Garantias Fundamentais na Constituição de 1988. São Paulo: Liber Juris.

CRETELLA JÚNIOR, José. Comentários a Lei do Mandado de Segurança. 9a ed. São Paulo: Forense, 1998, v.1.

DANTAS, Ivo. Direito Adquirido, Emendas Constitucionais e Controle da

Constitucionalidade. in Revista de Direto Administrativo, v. 206, out/dez 1996, Rio de Janeiro: Renovar, 1996.

DINIZ, Maria Helena. Lei de Introdução ao Código Civil Brasileiro Interpretada. São Paulo: Saraiva, 1994.

FRANCISCO, Caramuru Afonso. Do registro de imóveis e seu cancelamento. São Paulo: Juarez de Oliveira, 1999.

FRIEDE, Reis. Curso de direito constitucional e teoria geral do Estado. Rio de Janeiro:

Forense, 1999.

GOMES, Orlando. Direitos reais. Rio de Janeiro: Forense.

LOPES, Miguel Maria de Serpa. Tratado dos registros públicos: em comentário ao decreto $n^{o}$ 4.857, de 9 de novembro de 1939. $6^{\text {a }}$ ed. Brasília: Brasília Jurídica, 1996, V. II.

MACHADO, Hugo de Brito. Direito Adquirido e Coisa Julgada como Garantias Constitucionais, in Revista dos Tribunais, ano 84, abril/95, v. 714. São Paulo: Revista dos Tribunais, 1985.

MARTINS, Ricardo Marcondes. Loteamentos urbanos e desapropriação. in: Tratado de Direito Municipal. Valder do Nascimento [et al] (coord.). Belo Horizonte: Fórum, 2018. MEIRELLES, Hely Lopes. Direito Municipal brasileiro. 14. ed. São Paulo: Malheiros, 2006. MODESTO, Paulo. Reforma Administrativa e Direito Adquirido. in Revista de Direito Administrativo \& Constitucional, ano 01, n. ${ }^{\circ}$ 01, Curitiba: Juruá, 1999.

MUKAI, Toshio. Direito urbano e ambiental. 3. Ed. Belo Horizonte: Fórum, 2006. 
NUNES, Luiz Antônio. Manual de Introdução ao Estudo do Direito. São Paulo: Saraiva, 1996.

PEREIRA, Caio Mário da Silva. Instituições de Direito Civil. Rio de Janeiro: Forense, 1961.

PONTES DE MIRANDA, Francisco. Comentários à Constituição de 1967 com a Emenda $n^{o}$ 1 de 1969. Rio de Janeiro: Forense, 1987.

RÁO, Vicente. O Direito e a Vida dos Direitos. 3a. ed. São Paulo: Revista dos Tribunais.

SILVA, José Afonso. Aplicabilidade das normas constitucionais. $6^{\text {a }}$ ed. São Paulo: Malheiros, 2002.

SOARES, Orlando. Comentários à Constituição da República Federativa do Brasil: o

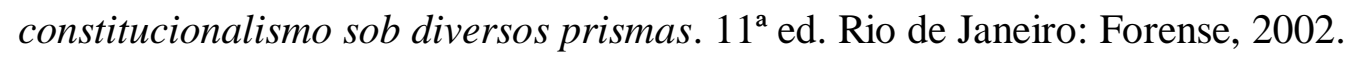

TAVARES, André Ramos. Planos urbanísticos na constituição econômica de 1988. In:

Tratado de Direito Municipal. NASCIMENTO, Valder do. [et al] (coord.). Belo Horizonte: Fórum, 2018.

WERNER, Patrícia Ulson Pizarro. Licenças urbanísticas. In: Temas de direito ambiental e urbanístico. FIGUEIREDO, Guilherme José Purvin de (org.). p. 301-323. São Paulo: Max Limonad, 1998. 